\title{
SOME FACTORS IN THE DEVELOPMENT OF CALLUS IN POPLAR CUTTINGS ${ }^{1}$
}

\author{
BY W. J. BLOOMBERG ${ }^{2}$
}

W. J. Bloomberg received his B.Sc. from the University of Wales, 1943. In 1947 he was employed by the Abitibi Power and Paper Co., Sault Ste. Marie, Ontario, in forest inventory. In 1948 he joined the Alberta Forest Service as assistant superintendent, Clearwater Forest Reserve. From 1953 to 1956 he was editor of Canadian Pulp and Paper Industry. In 1958 he joined the Forest Entomology and Pathology Laboratory, Victoria, B.C., where he has been doing research on poplar diseases, and more recently nursery diseases. He obtained his Ph.D. in Forest Pathology at the University of British Columbia in 1960.

\section{ABSTRACT}

The effect of temperature, moisture content of the cutting, and location within the shoot and cutting on callus production were investigated in Populus trichocarpa Torr. and Gray, $P$. canadensis Moench 'Regenerata', and $P$. canadensis 'Robusta Bachelieri'. Callus production increased with temperature and moisture cantent although not to the same extent in the three varieties. Cuttings from the base of the shoot produced more callus than those from the upper part. The latter cuttings produced more callus from the end which had been lowermost in the parent shoot than that which had been uppermost. However, cuttings from the base of the shoot showed this difference between ends of cuttings only in $P$. 'Regenerata'.

\section{INTRODUCTION}

From investigations into the development of adventitious roots in poplar cuttings it appears that some roots arise from callus tissue (Bier 1961, Bloomberg 1963). To learn more about the factors which influence callus formation, and therefore root development as well, experiments were carried out to determine the effects of temperature, moisture content of the shoot, and location within the shoot and within the cutting on the amount of callus tissue produced in cuttings of Populus trichocarpa Torr. and Gray, P. canadenis Moench 'Regenerata', and P. canadensis 'Robusta Bachelieri'.

Methods used to prepare cuttings were the same as those reported in a previous paper (Bloomberg 1963). Briefly, cuttings were made from vigorous 8-month-old shoots, approximately 7 feet long, collected in November. In each shoot, cuttings were taken from the region extending from the ground to a point one-quarter of the way up each shoot and from the region between the mid-point of the shoot and a point three-quarters of the way up the shoot. These were designated as basal and upper cuttings respectively.

\footnotetext{
${ }^{1}$ Contribution No. 1084 from the Forest Entomology and Pathology Branch, Department of Forestry, Ottawa, Canada.

${ }^{2}$ Forest Entomology and Pathology Laboratory, Victoria, B.C.
} 
The moisture content of the cuttings was brought to 50 or $100 \%$ of saturation and they were incubated at 5,15 , or $25^{\circ} \mathrm{C}$. in polyethylene bags. After 21 days, callus was excised from the ends of cuttings, dried to constant weight at $75-80^{\circ} \mathrm{C}$., and the weight expressed as milligrams per centimeter of circumference of the ends.

The experiments were factorial in design with 12 replications for each factor. A total of 72 cuttings was used. The data were statistically analysed after a transformation to $\log x$ which was used to correct heterogeneity of error. The values in Tables 1 and 2 must therefore be converted to $\log x$ in order to test for significant differences. All differences referred to are significant at the 5 or $1 \%$ level of probability.

\section{RESULTS}

In $\boldsymbol{P}$. trichocarpa and $\boldsymbol{P}$. 'Regenerata' more callus was produced by cuttings with a moisture content of $100 \%$ saturation than by those with $50 \%$; the ratio was 10 to 1 in $P$. trichocarpa and 3 to 1 in $P$. 'Regenerata' (Table 1).

TABLE 1

Effect Of Molsture Content In Poplar Cuttings On The Development Of Callus

\begin{tabular}{lcc}
\hline \multicolumn{1}{c}{ Variety } & $\begin{array}{c}\text { Moisture content } \\
\% \text { saturation }\end{array}$ & $\begin{array}{c}\text { Weight of callus } \\
\mathrm{mg} / \mathrm{cm} \text { of } \text { circumference }\end{array}$ \\
\hline $\boldsymbol{P}$. trichocarpa & 50 & 9.4 \\
& & $* * 1$ \\
$P$. 'Regenerata' & 100 & 126.0 \\
& 50 & 18.4 \\
$P$. 'Robusta' & 100 & 61.3 \\
& 50 & 66.6 \\
LSD Moisture contents & 100 & 84.2 \\
\hline
\end{tabular}

** Indicates a highly significant difference between the adjacent values.

Moisture content had no significant effect on callus production in $P$. 'Robusta'. Callus was produced at 15 and $25^{\circ} \mathrm{C}$. but not at $5^{\circ} \mathrm{C}$. In $P$. trichocarpa, four times as much callus was produced at $25^{\circ}$ as at $15^{\circ} \mathrm{C}$., but in the hybrids there was no significant difference in this respect. At these temperatures, cuttings from the basal region of the shoot in all varieties produced more callus than those from the upper region (Table 2). In all cuttings from the upper region of the shoot, the end of the cutting which had been lowermost in the parent shoot produced significantly more callus than the uppermost end; however, except for $P$. 'Regenerata' (Table 2), cuttings from the lower shoot showed no difference in this respect. Based on average values for all factors, $P$. 'Robusta' produced more callus $(41.7 \mathrm{mg}$ ) than either $P$. trichocarpa or $P$. 'Regenerata' ( $33.6 \mathrm{mg}$ each).

The findings agree generally with those of Swingle's studies (1929) on the effect of temperature, moisture and polarity of callus formation in willow 
TABLE 2

Effects Of Shoot Region And End Of Cutting On The Development Of Callus In Poplars

\begin{tabular}{|c|c|c|c|c|}
\hline \multirow{2}{*}{$\frac{\text { Variety }}{P . \text { trichocarpa }}$} & \multirow{2}{*}{\begin{tabular}{|l}
$\begin{array}{c}\text { Shoot } \\
\text { region }\end{array}$ \\
upper
\end{tabular}} & \multicolumn{3}{|c|}{$\begin{array}{l}\text { End of cutting } \\
\text { Upper } \\
\mathrm{mg} \text { callus } / \mathrm{cm} \text { circumference }\end{array}$} \\
\hline & & $\begin{array}{r}10.2 \\
* *\end{array}$ & $* * 1$ & $\begin{aligned} 21.0 \\
* *\end{aligned}$ \\
\hline & basal & 70.5 & & 84.7 \\
\hline \multirow[t]{2}{*}{ P. 'Regenerata' } & upper & $\begin{array}{r}3.9 \\
* *\end{array}$ & $* *$ & $\begin{array}{r}54.1 \\
* *\end{array}$ \\
\hline & basal & 52.8 & $* *$ & 112.9 \\
\hline \multirow[t]{2}{*}{$P$. 'Robusta' } & upper & $\begin{array}{r}37.1 \\
* *\end{array}$ & $*:$ & $\begin{array}{r}138.7 \\
* *\end{array}$ \\
\hline & basal & 85.7 & & 71.2 \\
\hline
\end{tabular}

$1 * *$ Indicates a highly significant difference between the adjacent values.

and apple cuttings, and with the observations of Bier (1961) regarding the presence of callus in $P$. 'Robusta' cuttings. The effects of the different factors on callus production were generally similar to their effects on adventitious root production (Bloomberg 1958, 1963). Therefore it appears that conditions which favor callus development also favor root production. Although $P$. trichocarpa was the least sensitive to temperature and moisture variation with respect to root production, this species was the most sensitive in terms of callus production. It can be inferred that under certain conditions in the field, $P$. trichocarpa will produce fewer callus-borne roots than the hybrids and may, in fact, be less dependent on them than on roots which do not arise from callus.

\section{ACKNOWLEDGEMENTS}

The critical reviews of the manuscript by Dr. R. E. Foster, head of forest pathology investigations, and other members of the research staff at the Forest Entomology and Pathology Laboratory, Victoria, are gratefully acknowledged.

\section{REFERENCES}

BIER, J. E. 1961. The relation of bark moisture content to the development of canker diseases caused by native, facultative parasites. 5. Rooting behaviour and disease vulnerability in cuttings of Populus trichocarpa Torr. and Gray , and P. 'Robusta'. Can. J. Botany 39, $145-154$.

BLOOMBERG, W. J. 1958. Root formation of black cottonwood cuttings in relation to region of parent shoot. For. Chron. 35, 13-17.

BLOOMBERG, W. J. 1963. The significance of initial adventitious roots in Populus and the effect of certain factors on their development. Forestry Chron. 39, 279-289.

SWINGLE, C. F. 1929. A physiological study of rooting and callusing in apple and willow. J. Agr. Research, 39, 81-128. 